\title{
Preoperative anaemia and red blood cell transfusion in patients with aneurysmal subarachnoid and intracerebral haemorrhage - A multicentre subanalysis of the German PBM Network Registry
}

\author{
Elke Schmitt \\ Department of Anaesthesiology, Intensive Care Medicine and Pain Therapy, University Hospital Frankfurt, Goethe University, Frankfurt \\ Patrick Meybohm \\ Department of Anaesthesiology, Intensive Care, Emergency and Pain Medicine, University Hospital Wuerzburg, Wuerzburg, Germany \\ Vanessa Neef \\ Department of Anaesthesiology, Intensive Care Medicine and Pain Therapy, University Hospital Frankfurt, Goethe University, Frankfurt \\ Peter Baumgarten \\ Department of Neurosurgery, University Hospital, Schiller University Jena, Jena, Germany
}

\section{Alexandra Bayer}

Department of Anesthesiology and Intensive Care Medicine, Krankenhaus Agatharied, Hausham, Academic Teaching Hospital of the Ludwig-Maximilians University of Munich

\section{Suma Choorapoikayil}

Department of Anaesthesiology, Intensive Care Medicine and Pain Therapy, University Hospital Frankfurt, Goethe University, Frankfurt

Patrick Friederich

Department of Anesthesiology, Operative Intensive Care Medicine and Pain Therapy, München Klinik Bogenhausen, Munich

Jens Friedrich

Department of Anesthesiology and Operative Intensive Care Medicine, Klinikum Leverkusen, Leverkusen

Christof Geisen

German Red Cross, Institute for Transfusion Medicine and Immunohematology, German Red Cross Baden-Wuertemberg - Hessen, Goethe University

Frankfurt, Frankfurt am Main, Germany

Erdem Güresir

Department of Neurosurgery, University Hospital Bonn, Bonn, Germany

Matthias Grünewald

Department of Anaesthesiology and Intensive Care Medicine, University Hospital Schleswig-Holstein, Kiel

Martin Gutjahr

Department of Anesthesiology, Marienhaus Klinikum St. Wendel-Ottweiler

Philipp Helmer

Department of Anaesthesiology, Intensive Care, Emergency and Pain Medicine, University Hospital Wuerzburg, Wuerzburg, Germany

Eva Herrmann

Institute of Biostatistics and Mathematical Modelling, Department of Medicine, Goethe University, Frankfurt

\section{Markus Müller}

German Red Cross, Institute for Transfusion Medicine and Immunohematology, German Red Cross Baden-Wuertemberg - Hessen, Goethe University

Frankfurt, Frankfurt am Main, Germany

\section{Diana Narita}

Institute for Laboratory Diagnostics and Transfusion Medicine, Donaulsar Klinikum, Deggendorf/Dingolfing/Landau

\section{Ansgar Raadts}

Department of Anesthesiology and Intensive Care Medicine, University Hospital Jena, Jena

\section{Klaus Schwendner}

Department of Anesthesiology and Operative Intensive Care Medicine, Diakonie hospital Martha-Maria, Nuremberg

Erhard Seifried

German Red Cross, Institute for Transfusion Medicine and Immunohematology, German Red Cross Baden-Wuertemberg - Hessen, Goethe University

Frankfurt, Frankfurt am Main, Germany

Patrick Stark

Department of Visceral and Vascular Surgery, Klinikum Mittelmosel, Zell, Germany (former affiliation at time of data provision); Department of Vascular Surgery, Katholisches Klinikum Koblenz, Koblenz

Andrea U. Steinbicker

Department of Anaesthesiology, Intensive Care and Pain Medicine, University Hospital Muenster, Muenster

Josef Thoma

Department of Anesthesiology and Operative Intensive Care Medicine, Ortenau Klinikum Offenburg-Kehl, Offenburg

Markus Velten 
Department of Anaesthesiology and Operative Intensive Care Medicine, University Hospital Bonn, Bonn

Henry Weigt

Department of Anesthesiology, SLK-Kliniken, Heilbronn

Christoph Wiesenack

Department of Anesthesiology, Protestant Deaconess Hospital Freiburg, Freiburg

Maria Wittmann

Department of Anaesthesiology and Operative Intensive Care Medicine, University Hospital Bonn, Bonn

Kai Zacharowski

Department of Anaesthesiology, Intensive Care Medicine and Pain Therapy, University Hospital Frankfurt, Goethe University, Frankfurt

Florian Piekarski ( $\square$ florian.piekarski@kgu.de)

Department of Anaesthesiology, Intensive Care Medicine and Pain Therapy, University Hospital Frankfurt, Goethe University, Frankfurt

\section{Research Article}

Keywords: Aneurysmal subarachnoid haemorrhage, intracerebral haemorrhage, anaemia, red blood cell transfusion, patient blood management

Posted Date: January 12th, 2022

DOI: https://doi.org/10.21203/rs.3.rs-1117815/v1

License: @ (i) This work is licensed under a Creative Commons Attribution 4.0 International License. Read Full License

Version of Record: A version of this preprint was published at Acta Neurochirurgica on February 26th, 2022. See the published version at https://doi.org/10.1007/s00701-022-05144-7. 


\section{Abstract \\ Purpose}

Anaemia is common in patients presenting with aneurysmal subarachnoid (aSAH) and intracerebral haemorrhage (ICH). In surgical patients, anaemia was identified as an idenpendent risk factor for postoperative mortality, prolonged hospital length of stay (LOS) and increased risk of red blood cell (RBC) transfusion. This multicentre cohort observation study describes the incidence and effects of preoperative anaemia in this critical patient collective for a 10year period.

\section{Methods}

This multicentre observational study included adult in-hospital surgical patients diagnosed with aSAH or ICH of 21 German hospitals (discharged from 1 January 2010 until 30 September 2020). Descriptive, univariate and multivariate analyses were performed to investigate the incidence and association of preoperative anaemia with RBC transfusion, in-hospital mortality and postoperative complications in patients with aSAH and ICH.

\section{Results}

A total of $n=9,081$ patients were analysed (aSAH $n=5,008 ; \mathrm{ICH} n=4,073$ ). Preoperative anaemia was present at $28.3 \%$ in aSAH and $40.9 \%$ in ICH. RBC transfusion rates were $29.9 \%$ in aSAH and $29.3 \%$ in ICH. Multivariate analysis revealed that preoperative anaemia is associated with a higher risk for RBC transfusion ( $\mathrm{OR}=3.25$ in aSAH, $\mathrm{OR}=4.16 \mathrm{in} \mathrm{ICH}, \mathrm{p}<0.001)$, for in-hospital mortality $(\mathrm{OR}=1.48$ in aSAH, $\mathrm{OR}=1.53$ in $\mathrm{ICH}, \mathrm{p}<0.001)$ and for several postoperative complications.

\section{Conclusions}

Preoperative anaemia is associated with increased RBC transfusion rates, in-hospital mortality and postoperative complications in patients with aSAH and $\mathrm{ICH}$.

\section{Trial registration:}

ClinicalTrials.gov, NCT02147795, https://clinicaltrials.gov/ct2/show/NCT02147795

\section{Background}

Anaemia is an independent risk factor for postoperative complications, mortality, prolonged hospital length of stay (LOS) and increased risk of red blood cell (RBC) transfusion [24]. The prevalence of anaemia is reported to be $22.8 \%$ globally and $26.5 \%-31.5 \%$ in patients undergoing surgery [10, 2], Preoperative anaemia was reported for $5.5 \%$ of patients suffering from aneurysmal subarachnoid haemorrhage (aSAH) [8] and for $24.1-25.8 \%$ of patients suffering from intracerebral haemorrhage $(\mathrm{ICH})[17,16]$. For patients with $\mathrm{ICH}$, anaemia has also been shown to be an independent predictor for unfavourable long-term outcomes a decade ago [17]. Kumar et al. demonstrated that anaemia is common in acute ICH patients and that its presence on admission is an independent predictor of increased ICH volume; contrary to pathophysiological considerations, however, in 2009, they could not demonstrate an effect on increased mortality [16].

Treatment of anaemia in emergency situations usually involves the administration of allogeneic blood products. The administration of RBC transfusions is known to be associated with multiple risks, such as transfusion-related lung injury, haemolytic reactions and transmission of infectious diseases [12]. RBC transfusions in patients undergoing cranial surgery is also associated with a prolonged LOS, more postoperative complications, a 30 -day return to the operating theatre and an increased 30-day mortality rate [4]. In patients with aSAH, RBC transfusions have been shown to result in increased mortality and general worse clinical outcomes [31].

This multicentre cohort study analyses the incidence of preoperative anaemia and its association with RBC transfusion requirements, hospital length of stay (LOS), in-hospital mortality and clinically relevant outcomes in patients with aSAH and ICH.

\section{Methods}

\section{Study design and objectives}

The current study is a subanalysis of the ongoing prospective multicentre observational study 'Safety and effectiveness of a Patient Blood Management (PBM) programme in surgical patients' (ClinicalTrials.gov, NCT02147795) [22]. The period analysed covered 1 January 2010 to 30 September 2020. Data from 23 hospitals was screened. The study was approved by the Ethics Committee of the University Hospital Frankfurt, Goethe University (first vote ref. 380/12 from 10 January 2013, amendments from 17 June 2013 and 1 June 2016, second vote ref. 318/17 from 30 November 2017), who waived the requirement for informed patient

sconsent. Inaddition, thelocalethicscommie eofeachparticipat $\in$ gcentrefollowedthisvote and likewisewaivedtherequirementf or $\in$ f or m $\epsilon$ s consent. 
The primary objective of the study was to assess the prevalence of preoperative anaemia and its association with RBC transfusion in aSAH or ICH patients. The secondary objective was to investigate the association of potential risk factors (such as preoperative anaemia, RBC transfusions and other factors related with the type of neurosurgical intervention, additional diagnoses and patient characteristics) with common clinical outcomes (including mortality, typical postoperative complications and LOS) in patients with aSAH and ICH (Online Resource 1).

\section{Patient enrolment and inclusion criteria}

The underlying PBM database contained by design adult ( $\geq 18$ years) in-hospital patients, who underwent surgery or a procedure (classified according to the Operation and Procedure Classification System (OPS) code (Online Resource 1)) during their hospital stay. Patients from the PBM database with a diagnosis of aSAH or ICH, defined by the International Classification of Disease (ICD-10) codes and discharged from hospital within the time period from 1 January 2010 to 30 September 2020, were included (Online Resource 1 and 2). Exclusion criteria were diagnoses of additional traumatic SAH and intracranial neoplasm (Online Resource 1). Patients were assigned to either the aSAH (patients diagnosed with aSAH with/without additional ICH) or the ICH group (patients diagnosed with ICH only) (Figure 1). This classification was chosen because an additional ICH can occur after the aetiological event of an aSAH, even though the patients were originally diagnosed only with aSAH. In the group of patients diagnosed with ICH only, ICH was the primary diagnosis and cause of hospitalisation.

\section{Definitions}

Anaemia was defined according to the WHO definition: Anaemia $\mathrm{Hb}<12 \mathrm{~g} / \mathrm{dl}(7.45 \mathrm{mmol} / \mathrm{l})$ (female) and Hb $<13 \mathrm{~g} / \mathrm{dl}(8.07 \mathrm{mmol} / \mathrm{l})$ (male); mild anaemia in female: $\mathrm{Hb} 11$ - $12 \mathrm{~g} / \mathrm{dl}(6.83$ - $7.45 \mathrm{mmol} / \mathrm{l})$; mild anaemia in male: $\mathrm{Hb} 11$ - $13 \mathrm{~g} / \mathrm{dl}$ (6.83 - 8.07 mmol/l); moderate anaemia in female and male: Hb 8 - $11 \mathrm{~g} / \mathrm{dl}$ (4.97- $6.83 \mathrm{mmol} / \mathrm{l})$; severe anaemia in female and male $\mathrm{Hb}<8 \mathrm{~g} / \mathrm{dl}(<4.97 \mathrm{mmol} / \mathrm{l})$ [27].

Preoperative anaemia status was based on the first available preoperative $\mathrm{Hb}$ value, and postoperative anaemia status was based on the last available $\mathrm{Hb}$ value before hospital discharge. Diagnostic criteria were defined by the relevant ICD-10 codes (Online Resource S1). Vasospasm was defined by ICD code 167.80. Interventions were defined by the relevant Operation and Procedure Classification (OPS) codes (Online Resource S1). Mortality was defined by the discharge code. Hospital LOS was defined by the given admission and discharge dates.

Data collectionThe underlying data source was anonymous routine data from hospital information systems (e.g. Agfa Orbis, Nexus, iMedOne, SAP) and additional data from individual blood bank and pharmacy software systems of the corresponding hospitals participating in the epidemiological research and quality management study of the German Patient Blood Management Network [22]. The data transferred to the PBM Network Coordination Centre did not contain any personal information. A data protection vote from the Hessian data protection officer was obtained (ref: 43.60; 60.01.21-ga from 24 October 2018). The biostatistician in charge subsequently evaluated the data for completeness and correctness and extracted the cases that fulfilled the inclusion criteria for this study before performing the final analysis.

\section{Statistical analysis}

Descriptive analysis was used to determine patient characteristics, the prevalence of pre- and postoperative anaemia, RBC transfusions, surgical interventions, and postoperative outcomes. The results of the descriptive analysis are presented as means ( \pm standard errors), medians (with first and third quartiles) and rates (with $95 \% \mathrm{Cl}$ ).

Multivariate mixed effect regression analysis was performed to identify independent predictors of RBC transfusion and various postoperative outcomes. The multivariate mixed effect regression models included the hospitals as random effects (to account for hospital individual effects) and other potentially relevant factors (such as age, gender, surgical interventions, preoperative anaemia, RBC consumption and vasospasm) as fixed effects.

Univariate non-parametric analysis (chi-square tests for binary endpoints and Wilcoxon-Mann-Whitney tests for continuous endpoints) was performed a-priori to assess the correlation of the individual factors where appropriate. To account for the heterogeneity of the aSAH and ICH groups, all analyses (univariate and multivariate) were performed separately by group.All analyses were performed using the free software R (Version 3.6.3).

\section{Results}

A total of $n=1,325,438$ patients from 23 hospitals were screened. Two hospitals in the network did not treat patients with neurosurgical diagnoses. Overall, $n$ $=9,081$ eligible patients from 21 hospitals were included and analysed in this study. The aSAH group included $n=5,008$ patients and the ICH group included $n$ $=4,073$ patients (Figure 1). The incidence of eligible cases within the entire database of $n=1,325,438$ was $0.4 \%$ for aSAH and $0.3 \%$ for ICH. Most patients received a neurosurgical OPS (84.9\% in aSAH and $76.9 \%$ in $\mathrm{ICH})$. The remaining OPS are distributed across several specialties (visceral and endocrine surgery accounts for the highest proportion with $5.0 \%$, followed by $3.5 \%$ with otorhinolaryngology). The distribution of other surgical OPS can be found in Online Resource 2). Demographic and intervention data are shown in Table 1.

Anaemia - The median preoperative $\mathrm{Hb}$ level was $13.2 \mathrm{~g} / \mathrm{dl}$ in aSAH patients and $12.8 \mathrm{~g} / \mathrm{dl}$ in ICH patients. Severe, moderate and mild preoperative anaemia was present in aSAH patients at rates of $1.0 \%, 10.7 \%$ and $16.6 \%$, respectively, and in ICH patients at rates of $2.7 \%, 17.6 \%$ and $20.6 \%$, respectively (Table 1 ).

Descriptive and univariate analysis for postoperative outcomes according to preoperative anaemia are listed for both pathologies in Tables $1 / 2$ and Online Resource Tables 3/4. Mortality was significantly higher in the presence of preoperative anaemia $(22.2 \%$ versus $13.3 \%, p<0.001$ in aSAH and $31.5 \%$ versus $17.9 \%, p<0.001$ in $\mathrm{ICH})($ Table 2). Figure 2 demonstrates that an increase in the preoperative $\mathrm{Hb}$ values corresponds to a decrease in the mortality rate. 
Descriptive and univariate analysis revealed that preoperative anaemia resulted in significantly higher numbers of RBC units transfused, LOS, postoperative anaemia, renal failure and sepsis both for aSAH und ICH patients (Tables $1 / 2 / 3$, Online Resource Tables $3 / 4$ ). Vasospasm was significantly lower in the presence of preoperative anaemia $(9.3 \%$ versus $12.4 \%, p=0.004)$ in aSAH patients (Table 1$)$. Multivariate analysis showed that preoperative anaemia was an independent risk factor for increased RBC transfusion in both, patients with aSAH $(p<0.001 ; \mathrm{OR}=3.25)$ and ICH $(p<0.001 ; \mathrm{OR}=4.16)(\mathrm{Table} 4 / 5)$. Multivariate analysis indicated preoperative anaemia was an independent risk factor for mortality $(\mathrm{OR}=1.48 \mathrm{in}$ aSAH patients, $\mathrm{OR}=1.53$ in ICH patients, both $p<0.001)$, transfused RBC units $(p<0.001)$, postoperative anaemia $(O R=6.18$ in aSAH patients, $O R=7.11$ in ICH patients, $p<0.001)$. In aSAH patients, moreover, preoperative anaemia increased the risk for renal failure $(O R=1.61, p=0.002)$ and LOS $(+1.6$ days, $p=0.03)$. Preoperative anaemia was an independent factor for decreased LOS in ICH $(;-2.5$ days, $p=0.006)$. Furthermore, preoperative anaemia was an independent factor for decreased ischemic stroke $(\mathrm{OR}=0.78, \mathrm{p}=0.005$ in aSAH and $\mathrm{OR}=0.82, \mathrm{p}=0.05$ in $\mathrm{ICH})$, pneumonia $(\mathrm{OR}=0.78$ in $\mathrm{ICH}, \mathrm{p}=0.008)$, pulmonary embolism $(\mathrm{OR}=0.60, \mathrm{p}=0.02$ in aSAH) and vasospasm (OR $=0.70, p=0.01$ in aSAH) $($ Table $5 / 6)$.

RBC transfusion - RBC transfusion rates were higher in the presence of preoperative anaemia in both, the aSAH group (45.8\% vs $24.9 \%, \mathrm{p}<0.001)$ and the ICH group ( $45.0 \%$ vs $18.8 \%, \mathrm{p}<0.001$ ), (Table 3 and Online Resource Tables $3 / 4$ ). Figure 3 demonstrates that a constant increase in the preoperative $\mathrm{Hb}$ values corresponds to a constant decrease in the RBC transfusion rate. Preoperative anaemic patients were significantly more likely to receive RBC transfusions than non-anaemic patients ( $24.9 \%$ vs. $45.8 \%, p<0.001$ in aSAH and $18.8 \%$ vs. $45.0 \%$, p $<0.001$ in ICH) (Table 3 and Online Resource Tables $3 / 4)$. In the additional descriptive analysis, transfusion rates for RBC, plasma and clotting products were higher when haemorrhagic diatheses due to coumarins, heparins and novel oral anticoagulants (NOACs), as well as factor XIII and factor VIII deficiency were present (Table 3/4). Mortality rates were higher when more RBC units were required (Table 2).

Multivariate analysis revealed that $\mathrm{RBC}$ transfusion was an independent (all $\mathrm{p}<0.001)$ risk factor for increased mortality $(\mathrm{OR}=3.59$ in ICH, $\mathrm{OR}=2.30$ in aSAH), LOS (+17.7 days in ICH, +13.7 days in aSAH), ischaemic stroke, renal failure, sepsis, pneumonia and pulmonary embolism in aSAH and ICH patients and for vasospasm $(\mathrm{OR}=2.47)$ in aSAH patients $($ Table $5 / 6)$.

Interventions - In the univariate and descriptive analysis, RBC transfusion rates were significantly $(\mathrm{p}<0.001)$ higher in the presence of interventions $($ Table 2 and Online Resource Tables 3/4). In the multivariate analysis, clipping was an independent factor for significantly lesser RBC units transfused (-679 units/1000 patients, $p=0.035)$ in aSAH patients. Coiling ( $O R=1.63, p<0.001)$ and craniotomy $(O R=2.30, p<0.001)$ were independent risk factors for significantly higher RBC transfusion rates in aSAH patients. Craniotomy was independently associated with significantly higher RBC transfusion rates $(\mathrm{OR}=$ $1.78, \mathrm{p}<0.001$ in $\mathrm{ICH}$ and $\mathrm{OR}=2.30, \mathrm{p}<0.001$ in aSAH) and RBC units transfused $(+1263$ units/1000 patients, $\mathrm{p}<0.001$ in ICH) $(\mathrm{Table} 5 / 6)$

Vasospasm - The proportion of preoperative anaemia was significantly lower $(p=0.004)$ in the vasospasm $(22.8 \%)$ group than in the non-vasospasm group (29.0\%). The RBC transfusion rate was significantly higher $(p<0.001)$ in the vasospasm $(40.9 \%)$ than in the non-vasospasm group $(28.1 \%)(0 n l i n e$ Resource 5). In the multivariate analysis, vasospasm was an independent risk factor for $R B C$ transfusion $(O R=2.13, p<0.001)$, postoperative anaemia $(O R=1.67, p=$ 0.004), prolonged LOS (+6.1 days, $p<0.001)$, pneumonia $(O R=1.45, p<0.001)$ and ischemic stroke $(O R=1.45, p=0.001)(T a b l e s 3 / 4)$.

\section{Discussion}

The data revealed in both, aSAH and ICH patients, that preoperative anaemia is associated with a higher RBC transfusion rate, increased postoperative inhospital mortality and increased complication rates. These findings align with study results for other patient cohorts. Thus, in neurosurgical patients, preoperative anaemia has been shown to be an independent risk factor for postoperative mortality and increased risk of RBC transfusion [24]. Anaemia is common in aSAH patients $[30,14,8,33]$ and in ICH patients $[17,16]$. In this study, the prevalence of preoperative anaemia in both groups (aSAH $28.3 \%$ and $\mathrm{ICH} 40.9 \%$ ) was higher than described in previous publications (aSAH 5.5\% and ICH 24.1-25.8\%) $[8,17,16]$. One explanation for this could be that the database only includes cohorts of patients who underwent surgery or other interventions (e.g., coiling) during a hospital stay, so that selection bias cannot be ruled out.

The physiological and pathophysiological impact of anaemia in patients with aSAH and ICH is multifactorial. The supply of oxygen to the brain depends on several variables. Cerebral oxygen availability $\left(\mathrm{DO}_{2}\right)$ is the product of cerebral blood flow $(\mathrm{CBF})$ and arterial oxygen content $(\mathrm{CaO}) .: \mathrm{DO} 2=\mathrm{CBF} \times \mathrm{CaO} 2[19]$. The oxygen content $\left(\mathrm{CaO}_{2}\right)$ itself is represented by the formula $\mathrm{CaO}_{2}=\left(1.31 \times \mathrm{Hb} \times \mathrm{SaO}_{2} \times 0.01\right)+\left(0.0225 \times \mathrm{PaO}_{2}\right)$ and thus depends on $\mathrm{Hb}$ levels, arterial oxygen saturation $\left(\mathrm{SaO}_{2}\right)$ and arterial oxygen pressure $\left(\mathrm{PaO}_{2}\right)$ [7]. The formula demonstrates that apart from an increase in SaO for optimising the $\mathrm{DO}_{2}$ to the target cell is the $\mathrm{Hb}$ value; thus, the need arises to consider ways of increasing the $\mathrm{Hb}$ value through various measures (such as anaemia management or transfusion in an emergency). In healthy brain, a progressive decrease in $\mathrm{Hb}$ is compensated for by vasodilation, resulting in increased $\mathrm{CBF}$ and a constant cerebral oxygen supply $\mathrm{DO}_{2}$. When $\mathrm{Hb}$ falls below $5-6 \mathrm{~g} / \mathrm{dL}, \mathrm{DO}_{2}$ decreases and no further vasodilation can occur and maximum CBF levels are reached [19]. We observed that the vasospasm rate was significantly lower with preoperative anaemia. It is possible, that the Hb value influences only patients' outcomes after cerebral vasospasm and not the probability of a cerebral vasospasm event itself. The multivariate analysis also revealed a significant association of RBC transfusion ( $O R=2.47, p<0.001)$ with vasospasm. This finding underlines the need for risk assessment prior to transfusion and additional prospective studies on this topic. Scholars have long debated whether elevating the haemoglobin levels in SAH patients with vasospasm and thus avoiding anaemia is beneficial $[15,29,18]$. In general, based on CONSCIOUS-3, the role of vasospasm on delayed cerebral ischemia should be considered with caution, where clazosentan was shown to significantly reduce postaSAH vasospasm, but neither dose improved outcome [20]. Further studies are needed to prove the potential beneficial effects of RBC transfusion on anaemic aSAH patients suffering from cerebral vasospasm. In the field of critical care, there is a growing evidence that strict transfusion limits remain best practice for the vast majority of cases, due to limited adverse effects, comparable or better clinical outcomes and economic aspects [28]. Thus, a restrictive threshold for RBC transfusions $(\mathrm{Hb}<7 \mathrm{~g} / \mathrm{dl})$ is still recommended in both critically ill and clinically stable ICU patients [23]. Similar pathophysiological considerations are known in patients with acute myocardial infarction, as a recent study demonstrated that a restrictive transfusion strategy resulted in less major adverse cardiac events after 30 days (11.0\% in the restrictive and $14.0 \%$

Page 5/18 
in the liberal group) [6]. In the retrospective study by English et al., only $20 \%$ of patients with aSAH received RBC transfusions, mostly in the presence of significant anaemia $(\mathrm{Hb}<8 \mathrm{~g} / \mathrm{dl})$, and this was not associated with worse outcomes [8]. However, Dhar et al. demonstrated that RBC transfusion in aSAH patients improved cerebral oxygenation both globally and particularly in the vulnerable brain regions and thus may potentially minimise the risk for delayed cerebral ischaemia. The study analysed the outcomes over a wide range of haemoglobin levels and suggests that restrictive transfusion practice may not be appropriate in this vulnerable population [5]. Naidech et al. demonstrated no difference in outcomes in SAH for Hb 10.0 versus $11.5 \mathrm{~g} / \mathrm{dL}$. Here, however, the difference between the groups is rather minor and well above general limits for transfusions [25]. The answer to the question of the role of treatment of anaemia with red blood cell transfusion could be provided by the still ongoing SAHaRA trial [9]. In our analysis, mortality was increased considerably the more transfusions were given, which is also in line with the results from Ceanga et al. [3].

Although preoperative diagnosis and treatment of anaemia can only be implemented to a limited extent in acute situations of ICH and aSAH, the present data underlines primarily the importance of general anaemia vigilance and treatment (as ICH and aSAH occur sudden and without time frame for treatment), and secondarily, anaemia treatment becomes important in the context of peri-/postoperative care. To identify and manage anaemia at an early stage, a multimodal therapy using patient blood management (PBM) has been developed. PBM is an evidence-based, patient-centred and multidisciplinary approach to minimise anaemia-associated risks, unnecessary blood loss and transfusions in patients undergoing surgery [1]. For this purpose, measures have been implemented to reduce preoperative anaemia, minimise iatrogenic blood loss and optimise patient-specific anaemia tolerance [11]. If iron deficiency is identified in the absence of infection, iron supplementation and erythropoiesis-stimulating agents can be considered [13]. Measures to reduce intraoperative blood loss and optimise coagulopathy should be implemented. This includes the following measures (also in neurosurgery): Treatment of coagulopathy should be based on a fixed algorithm. The content of the coagulation algorithm should be the maintenance of basic conditions for haemostasis (body temperature $>36^{\circ} \mathrm{C}$, ionised calcium $>1.1 \mathrm{mmol} / \mathrm{L}, \mathrm{pH}>7.2$ ) or point-of-care diagnostics. The prevalence of bleeding due to anticoagulation was low in our analysis but point of care technology provides information on coagulation dysfunction and the use of anticoagulation, including NOACs. The use of an antifibrinolytic is safe and recommended [32]. Blood sample collections should be reduced to the absolute necessary numbers, blood sample collection tubes should draw as little blood volume as possible, and return systems for blood sample collections should be established. Washed cell salvage-the collection, washing and retransfusion of a patient's own wound blood-can help to reduce the need for blood from other sources [26, 21].

\section{Limitations}

Although studies with routine data have several important advantages over traditional clinical trials (such as a larger number of cases with fewer personnel, time and cost requirements) and are therefore becoming increasingly popular as an alternative in the age of advancing digitalisation, they naturally also have some disadvantages. This study is based on routine data of hospital information systems. Data quantity and quality varied between hospitals. In addition, routine data may have some other limitations, in general, such as missing data or incorrect coding techniques. Since ICD and OPS codes are billing-related, they may be biased.

Furthermore, there is no information on the exact time of occurrence and duration of complications and perioperative interventions (including blood transfusions), so an association does not necessarily indicate causality, nor is it possible to show the direction of causality. For this reason, we report associations rather than causalities of the factors.

Missing information on neurological status, resuscitation and intercurrent diseases cannot be obtained from the register, so that a limitation in the analysis of associations with anaemia and transfusion is possible here. The analysis could not consider the influence of a potential -and already locally available anaemia therapy. The Hunt and Hess scale for aSAH, which measures the severity of the aSAH, is not documented in ICD-10 codes; therefore, a severityadapted evaluation was not possible. In neurosurgical therapy, patients are often transferred to a rehabilitation intensive care unit or back to the referring intensive care unit shortly after treatment; this leads to a possible bias in endpoints (e.g., especially for LOS). This is a retrospective analysis of prospectively collected registry data; limitations of a retrospective analysis cannot be avoided.

\section{Conclusions}

Preoperative anaemia is associated with increased RBC transfusion rates, in-hospital mortality, and postoperative complications in patients with aSAH and $\mathrm{ICH}$. Prospective multicentre studies with tailored data on the therapy of anaemia, the optimal haemoglobin value and transfusion strategy, both for aSAH and ICH patients, are urgently needed.

\section{Abbreviations}

aSAH

Aneurysmal subarachnoid haemorrhage

$\mathrm{Cl}$

Confidence interval

$\mathrm{Hb}$

Haemoglobin

ICD

International Classification of Disease

$\mathrm{ICH}$

Intracerebral haemorrhage

IQR 
Interquartile range

LOS

Length of in-hospital stay

NOAC

Novel oral anticoagulants

OPS

Operation and Procedure Classification

OR

Odds ratio

RBC

Red blood cells

SE

Standard error

\section{Declarations}

\section{Acknowledgments}

The German Patient Blood Management (PBM) Network with the associated registry was awarded the Lohfert Prize by the Lohfert Foundation in 2014, the German Prize for Patient Safety by Aktionsbündnis Patientensicherheit e.V. in 2016, the Humanitarian Award by the Patient Safety and Movement Foundation in 2016 and the MSD Health Prize by MSD SHARP \& DOHME GMBH, Germany ( $3^{\text {rd }}$ place) in 2018. We would like to express our sincere thanks for these honours.

We also wish to thank the IT staff of the participating centres for providing routine and additional data. In addition, we would like to thank the medical staff of each centre for their efforts in the practical implementation of PBM. We thank Dr. Christoph Füllenbach for his previous general support for the PBM project.

\section{Ethics approval and consent to participate}

The study was approved by the Ethics Committee of the University Hospital Frankfurt, Goethe University (first vote ref. 380/12 from 10 January 2013, amendments from 17 June 2013 and 1 June 2016, second vote ref. 318/17 from 30 November 2017), who waived the requirement for informed patient`s consent.

\section{Consent for publication}

Not applicable

\section{Availability of data and materials}

The data that support the findings of this study are available from the corresponding author upon reasonable request.

\section{Competing interests}

PM received honoraria for scientific lectures from Belgian Red Cross, Biotest, CSL Behring GmbH, Bundesamt für Bevölkerungsschutz und Katastrophenhilfe (BKK), Fresenius, Haemonetics, Landesärztekammer Sachsen, Landesärztekammer Hessen, Masimo, Radiometer, Schöchl medical Education, Thieme-Verlag, Trillium Diagnostik, Werfen GmbH, ViforPharma GmbH. PB received travel grants from Roche and Medac. KZ and his department received support from B. Braun Melsungen, CSL Behring, Fresenius Kabi, and Vifor Pharma for the implementation of Frankfurt's Patient Blood Management program and received honoraria for scientific lectures from CSL Behring, implatcast GmbH, med Update GmbH, Pharmacosmos and Vifor Pharma. MG received honoraria for scientific lectures from CSL Behring and Vifor Pharma. FP received honoraria from Pharmacosmos for scientific lectures.

\section{Funding}

The study was conducted with internal department funding, and with support from B. Braun Melsungen, CSL Behring, Fresenius Kabi, and Vifor Pharma for the implementation of Patient Blood Management program.

\section{Authors' contributions}

ESC, PM, EG, FP, PB, KZ developed the medical study concept. ESC, FP, PM developed the statistical study design. ESC, MV, DN, CW, AB, HW, AR, MG, JF, MG, MGR, MW, PF, AUS, KS, JT, PS collected the data. ESC performed the statistical analysis and interpreted the results statistically. PM, PB, EG, KZ, and FP interpreted the outcome medically. ESC, PM, FP prepared the first draft of the manuscript. All authors provided input and critical review of the manuscript leading to the final version. All authors read and approved the final manuscript.

\section{References}

1. Althoff FC, Neb H, Herrmann E, Trentino KM, Vernich L, Fullenbach C, Freedman J, Waters JH, Farmer S, Leahy MF, Zacharowski K, Meybohm P, Choorapoikayil S (2019) Multimodal Patient Blood Management Program Based on a Three-pillar Strategy: A Systematic Review and Meta-analysis. Ann 
2. Baron DM, Hochrieser H, Posch M, Metnitz B, Rhodes A, Moreno RP, Pearse RM, Metnitz P, European Surgical Outcomes Study group for Trials Groups of European Society of Intensive Care M, European Society of A (2014) Preoperative anaemia is associated with poor clinical outcome in non-cardiac surgery patients. Br J Anaesth 113:416-423. doi:10.1093/bja/aeu098

3. Ceanga Al, Ceanga M, Eveslage M, Herrmann E, Fischer D, Haferkamp A, Wittmann M, Muller S, Van Aken H, Steinbicker AU (2018) Preoperative anemia and extensive transfusion during stay-in-hospital are critical for patient's mortality: A retrospective multicenter cohort study of oncological patients undergoing radical cystectomy. Transfus Apher Sci 57:739-745. doi:10.1016/j.transci.2018.08.003

4. Cohen JA, Alan N, Seicean A, Weil RJ (2017) Risk associated with perioperative red blood cell transfusion in cranial surgery. Neurosurg Rev 40:633-642. doi:10.1007/s10143-017-0819-y

5. Dhar R, Zazulia AR, Derdeyn CP, Diringer MN (2017) RBC Transfusion Improves Cerebral Oxygen Delivery in Subarachnoid Hemorrhage. Crit Care Med 45:653-659. doi:10.1097/CCM.0000000000002266

6. Ducrocq G, Gonzalez-Juanatey JR, Puymirat E, Lemesle G, Cachanado M, Durand-Zaleski I, Arnaiz JA, Martinez-Selles M, Silvain J, Ariza-Sole A, Ferrari E, Calvo G, Danchin N, Avendano-Sola C, Frenkiel J, Rousseau A, Vicaut E, Simon T, Steg PG, Investigators R (2021) Effect of a Restrictive vs Liberal Blood Transfusion Strategy on Major Cardiovascular Events Among Patients With Acute Myocardial Infarction and Anemia: The REALITY Randomized Clinical Trial. JAMA 325:552-560. doi:10.1001/jama.2021.0135

7. Dunn J-O, Mythen M, Grocott M (2016) Physiology of oxygen transport. Bja Education 16:341-348

8. English SW, Chasse M, Turgeon AF, Lauzier F, Griesdale D, Garland A, Fergusson D, Zarychanski R, van Walraven C, Montroy K, Ziegler J, Dupont-Chouinard R, Carignan R, Dhaliwal A, Mallick R, Sinclair J, Boutin A, Pagliarello G, Tinmouth A, Mclntyre L, Canadian Critical Care Trials G (2018) Anemia prevalence and incidence and red blood cell transfusion practices in aneurysmal subarachnoid hemorrhage: results of a multicenter cohort study. Crit Care 22:169. doi:10.1186/s13054-018-2089-7

9. English SW, Fergusson D, Chasse M, Turgeon AF, Lauzier F, Griesdale D, Algird A, Kramer A, Tinmouth A, Lum C, Sinclair J, Marshall S, Dowlatshahi D, Boutin A, Pagliarello G, Mclntyre LA, Canadian Critical Care Trials G (2016) Aneurysmal SubArachnoid Hemorrhage-Red Blood Cell Transfusion And Outcome (SAHaRA): a pilot randomised controlled trial protocol. BMJ Open 6:e012623. doi:10.1136/bmjopen-2016-012623

10. Gardner W, Kassebaum N (2020) Global, Regional, and National Prevalence of Anemia and Its Causes in 204 Countries and Territories, $1990-2019$. Current Developments in Nutrition 4:830-830. doi:10.1093/cdn/nzaa053_035

11. Goodnough LT, Shander A (2012) Patient blood management. Anesthesiology 116:1367-1376. doi:10.1097/ALN.0b013e318254d1a3

12. Hendrickson JE, Hillyer CD (2009) Noninfectious serious hazards of transfusion. Anesth Analg 108:759-769. doi:10.1213/ane.0b013e3181930a6e

13. Investigators I, Litton E, Baker S, Erber WN, Farmer S, Ferrier J, French C, Gummer J, Hawkins D, Higgins A, Hofmann A, De Keulenaer B, McMorrow J, Olynyk JK, Richards T, Towler S, Trengove R, Webb S, Australian, New Zealand Intensive Care Society Clinical Trials G (2016) Intravenous iron or placebo for anaemia in intensive care: the IRONMAN multicentre randomized blinded trial: A randomized trial of IV iron in critical illness. Intensive Care Med 42:1715-1722. doi:10.1007/s00134-016-4465-6

14. Kramer AH, Gurka MJ, Nathan B, Dumont AS, Kassell NF, Bleck TP (2008) Complications associated with anemia and blood transfusion in patients with aneurysmal subarachnoid hemorrhage. Crit Care Med 36:2070-2075. doi:10.1097/CCM.0b013e31817c1095

15. Kumar MA, Levine J, Faerber J, Elliott JP, Winn HR, Doerfler S, Le Roux P (2017) The Effects of Red Blood Cell Transfusion on Functional Outcome after Aneurysmal Subarachnoid Hemorrhage. World Neurosurg 108:807-816. doi:10.1016/j.wneu.2017.09.038

16. Kumar MA, Rost NS, Snider RW, Chanderraj R, Greenberg SM, Smith EE, Rosand J (2009) Anemia and hematoma volume in acute intracerebral hemorrhage. Crit Care Med 37:1442-1447. doi:10.1097/CCM.0b013e31819ced3a

17. Kuramatsu JB, Gerner ST, Lucking H, Kloska SP, Schellinger PD, Kohrmann M, Huttner HB (2013) Anemia is an independent prognostic factor in intracerebral hemorrhage: an observational cohort study. Crit Care 17:R148. doi:10.1186/cc12827

18. Le Roux PD, Participants in the International Multi-disciplinary Consensus Conference on the Critical Care Management of Subarachnoid H (2011) Anemia and transfusion after subarachnoid hemorrhage. Neurocrit Care 15:342-353. doi:10.1007/s12028-011-9582-z

19. Lelubre C, Bouzat P, Crippa IA, Taccone FS (2016) Anemia management after acute brain injury. Crit Care 20:152. doi:10.1186/s13054-016-1321-6

20. Macdonald RL, Higashida RT, Keller E, Mayer SA, Molyneux A, Raabe A, Vajkoczy P, Wanke I, Bach D, Frey A, Nowbakht P, Roux S, Kassell N (2012) Randomized trial of clazosentan in patients with aneurysmal subarachnoid hemorrhage undergoing endovascular coiling. Stroke 43:1463-1469. doi:10.1161/STROKEAHA.111.648980

21. Meybohm P, Choorapoikayil S, Wessels A, Herrmann E, Zacharowski K, Spahn DR (2016) Washed cell salvage in surgical patients: A review and metaanalysis of prospective randomized trials under PRISMA. Medicine (Baltimore) 95:e4490. doi:10.1097/MD.0000000000004490

22. Meybohm P, Fischer DP, Geisen C, Muller MM, Weber CF, Herrmann E, Steffen B, Seifried E, Zacharowski K, German PBMSCG (2014) Safety and effectiveness of a Patient Blood Management (PBM) program in surgical patients-the study design for a multi-centre prospective epidemiologic noninferiority trial. BMC Health Serv Res 14:576. doi:10.1186/s12913-014-0576-3

23. Mueller MM, Van Remoortel H, Meybohm P, Aranko K, Aubron C, Burger R, Carson JL, Cichutek K, De Buck E, Devine D, Fergusson D, Follea G, French C, Frey KP, Gammon R, Levy JH, Murphy MF, Ozier Y, Pavenski K, So-Osman C, Tiberghien P, Volmink J, Waters JH, Wood EM, Seifried E, Group IPF (2019) Patient Blood Management: Recommendations From the 2018 Frankfurt Consensus Conference. JAMA 321:983-997. doi:10.1001/jama.2019.0554

24. Musallam KM, Tamim HM, Richards T, Spahn DR, Rosendaal FR, Habbal A, Khreiss M, Dahdaleh FS, Khavandi K, Sfeir PM, Soweid A, Hoballah JJ, Taher AT, Jamali FR (2011) Preoperative anaemia and postoperative outcomes in non-cardiac surgery: a retrospective cohort study. Lancet 378:1396-1407. doi:10.1016/S0140-6736(11)61381-0 
25. Naidech AM, Shaibani A, Garg RK, Duran IM, Liebling SM, Bassin SL, Bendok BR, Bernstein RA, Batjer HH, Alberts MJ (2010) Prospective, randomized trial of higher goal hemoglobin after subarachnoid hemorrhage. Neurocrit Care 13:313-320. doi:10.1007/s12028-010-9424-4

26. Neef V, Vo L, Herrmann E, Triphaus C, Judd L, Winter A, Zacharowski K, Choorapoikayil S, Meybohm P (2021) The association between intraoperative cell salvage and red blood cell transfusion in cardiac surgery - an observational study in a patient blood management centre. Anaesthesiol Intensive Ther 53:1-9. doi:10.5114/ait.2021.103735

27. World Health Organization (2011) Haemoglobin concentrations for the diagnosis of anaemia and assessment of severity. World Health Organization,

28. Rauer MJ, Neef V, Berra L (2021) Severe bleeding in the ICU. Curr Opin Anaesthesiol 34:530-536. doi:10.1097/AC0.0000000000001019

29. Rosenberg NF, Koht A, Naidech AM (2013) Anemia and transfusion after aneurysmal subarachnoid hemorrhage. J Neurosurg Anesthesiol 25:66-74. doi:10.1097/ANA.0b013e31826cfc1d

30. Sampson TR, Dhar R, Diringer MN (2010) Factors associated with the development of anemia after subarachnoid hemorrhage. Neurocrit Care 12:4-9. doi:10.1007/s12028-009-9273-1

31. Smith MJ, Le Roux PD, Elliott JP, Winn HR (2004) Blood transfusion and increased risk for vasospasm and poor outcome after subarachnoid hemorrhage. J Neurosurg 101:1-7. doi:10.3171/jns.2004.101.1.0001

32. Taeuber I, Weibel S, Herrmann E, Neef V, Schlesinger T, Kranke P, Messroghli L, Zacharowski K, Choorapoikayil S, Meybohm P (2021) Association of Intravenous Tranexamic Acid With Thromboembolic Events and Mortality: A Systematic Review, Meta-analysis, and Meta-regression. JAMA Surg:e210884. doi:10.1001/jamasurg.2021.0884

33. Wartenberg KE, Schmidt JM, Claassen J, Temes RE, Frontera JA, Ostapkovich N, Parra A, Connolly ES, Mayer SA (2006) Impact of medical complications on outcome after subarachnoid hemorrhage. Crit Care Med 34:617-623; quiz 624. doi:10.1097/01.ccm.0000201903.46435.35

\section{Tables}

Table 1) Patient characteristics, interventions and anaemia prevalence 


\begin{tabular}{|c|c|c|c|}
\hline & & $\begin{array}{l}\text { Aneurysmal subarachnoid haemorrhage } \\
(n=5,008)\end{array}$ & $\begin{array}{l}\text { Intracerebral haemorrhage } \\
(n=4,073)\end{array}$ \\
\hline \multicolumn{2}{|l|}{ Age at admission (years) } & $57.9 \pm 0.2,57.0(49.0 ; 68.0), \min =18, \max =96$ & $65.5 \pm 0.2,68.0(57.0 ; 77.0), \min =18, \max =97$ \\
\hline \multirow{2}{*}{\multicolumn{2}{|c|}{ Gender }} & Female: $61.7 \% ; n=3,088 / 5,008$ & Female: $42.4 \% ; n=1,727 / 4,073$ \\
\hline & & Male: $38.3 \% ; n=1,920 / 5,008$ & Male: $57.6 \% ; n=2,346 / 4,073$ \\
\hline \multicolumn{2}{|l|}{ Clipping } & $36.1 \%(34.8 \%-37.5 \%) ; n=1,809 / 5,008$ & - \\
\hline \multicolumn{2}{|l|}{ Coiling } & $27.8 \%(26.5 \%-29.0 \%) ; n=1,390 / 5,008$ & - \\
\hline \multicolumn{2}{|l|}{ Craniotomy } & $46.6 \%(45.2 \%-48.0 \%) ; n=2,335 / 5,008$ & $44.6 \%(43.1 \%-46.2 \%) ; n=1,817 / 4,073$ \\
\hline \multicolumn{2}{|c|}{ Additionally present intracerebral haemorrhage } & $23.9 \%(22.8 \%-25.1 \%), n=1,199 / 5,008$ & - \\
\hline \multicolumn{2}{|l|}{ Vasospasm } & $13.4 \%(12.5 \%-14.4 \%) ; n=672 / 5,008$ & - \\
\hline \multicolumn{2}{|c|}{ In preoperative anaemic patients } & $9.3 \%(7.7 \%-11.0 \%) ; n=113 / 1,218$ & - \\
\hline \multicolumn{2}{|c|}{ In preoperative non-anaemic patients } & $12.4 \%(11.3 \%-13.6 \%) ; n=383 / 3,086$ & - \\
\hline \multicolumn{2}{|l|}{ Preoperative Hb (g/dl) } & $13.1( \pm 0.0), 13.2(12.1 ; 14.4)$ & $12.8( \pm 0.0), 13.0(11.4 ; 14.3)$ \\
\hline \multicolumn{2}{|l|}{ Preoperative anaemia } & $28.3 \%(27.0 \%-29.7 \%) ; n=1,218 / 4,304$ & $40.9 \%$ (39.3 \% - $42.6 \%) ; n=1,421 / 3,474$ \\
\hline \multicolumn{2}{|l|}{ In male } & $29.5 \%(27.3 \%-31.8 \%) ; n=488 / 1,652$ & $42.5 \%(40.4 \%-44.7 \%) ; n=855 / / 2,010$ \\
\hline \multicolumn{2}{|l|}{ In female } & $27.5 \%(25.8 \%-29.3 \%) ; n=730 / 2,652$ & $38.7 \%(36.2 \%-41.2 \%) ; n=566 / 1,464$ \\
\hline \multirow[t]{4}{*}{ Preoperative anaemia levels } & None & $71.7 \% ; n=3,086 / 4,304$ & $59.1 \% ; n=2,053 / 3,474$ \\
\hline & Mild & $16.6 \% ; n=713 / 4,304$ & $20.6 \% ; n=716 / 3,474$ \\
\hline & Moderate & $10.7 \% ; n=462 / 4,304$ & $17.6 \% ; n=610 / 3,474$ \\
\hline & Severe & $1.0 \% ; n=43 / 4,304$ & $2.7 \% ; n=95 / 3,474$ \\
\hline \multicolumn{2}{|l|}{ Postoperative $\mathrm{Hb}(\mathrm{g} / \mathrm{dl})$} & $10.7( \pm 0.0), 10.5(9.3 ; 11.9)$ & $10.5( \pm 0.0), 10.3(8.9 ; 11.9)$ \\
\hline \multicolumn{2}{|l|}{ Postoperative anaemia } & $80.9 \%(79.8 \%-82.0 \%) ; n=3,898 / 4,818$ & $83.1 \%(81.9 \%-84.3 \%) ; n=3,275 / 3,659$ \\
\hline \multicolumn{2}{|c|}{ In preoperative anaemic patients } & $95.3 \%(94.0 \%-96.4 \%) ; n=1,142 / 1,218$ & $96.0 \%(94.9 \%-97.0 \%) ; n=1,349 / 1,421$ \\
\hline \multicolumn{2}{|c|}{ In preoperative non-anaemic patients } & $77.1 \%(75.5 \%-78.6 \%) ; n=2,334 / 3,086$ & $73.1 \%(71.1 \%-75.1 \%) ; n=1,478 / 2,053$ \\
\hline \multicolumn{2}{|l|}{ Hospital-acquired anaemia } & $77.1 \%(75.5 \%-78.6 \%) ; n=2,334 / 3,028$ & $73.1 \%(71.1 \%-75.1 \%) ; n=1,478 / 2,021$ \\
\hline \multicolumn{2}{|c|}{ Haemorrhagic diathesis due to coumarins } & $1.3 \%(1.0 \%-1.6 \%) ; n=63 / 5,008$ & $4.2 \%(3.6 \%-4.9 \%) ; n=173 / 4,073$ \\
\hline \multicolumn{2}{|c|}{ Haemorrhagic diathesis due to heparins } & $0.7 \%(0.5 \%-0.9 \%) ; n=34 / 5,008$ & $0.7 \%(0.5 \%-1.0 \%) ; n=28 / 4,073$ \\
\hline \multicolumn{2}{|c|}{ Haemorrhagic diathesis due to NOACs } & $1.2 \%(0.9 \%-1.6 \%) ; n=61 / 5,008$ & $4.4 \%(3.8 \%-5.1 \%) ; n=180 / 4,073$ \\
\hline \multicolumn{2}{|l|}{ Factor XIII deficiency } & $0.3 \%(0.1 \%-0.4 \%) ; n=13 / 5,008$ & $0.6 \%(0.4 \%-0.9 \%) ; n=25 / 4,073$ \\
\hline \multicolumn{2}{|l|}{ Factor VIII deficiency } & $0.5 \%(0.3 \%-0.7 \%) ; n=23 / 5,008$ & $0.4 \%(0.2 \%-0.6 \%) ; n=15 / 4,073$ \\
\hline \multicolumn{2}{|l|}{ Left Ventricular Assist Device } & $0.2 \%(0.1 \%-0.3 \%) ; n=8 / 5,008$ & $0.5 \%(0.3 \%-0.8 \%) ; n=21 / 4,073$ \\
\hline \multicolumn{2}{|c|}{ Extracorporeal membrane oxygenation } & $0.7 \%(0.5 \%-0.9 \%) ; n=33 / 5,008$ & $0.7 \%(0.4 \%-1.0 \%) ; n=27 / 4,073$ \\
\hline \multicolumn{2}{|l|}{ Extracorporeal life support } & $0.3 \%(0.2 \%-0.5 \%) ; n=16 / 5,008$ & $0.6 \%(0.4 \%-0.9 \%) ; n=25 / 4,073$ \\
\hline
\end{tabular}

Table 1 shows the patient characteristics, interventions and anaemia prevalence. Anaemia rates are calculated only from the subset of patients, of whom the required pre- and/or postoperative $\mathrm{Hb}$ values were available. The exact numbers are given per individual line. All values are represented as mean ( $\pm \mathrm{SE}$ ), median (IQR) or as rate $(95 \% \mathrm{Cl})$ and total number.

Table 2) Postoperative outcomes (LOS, mortality, complications) 
Outcome

Length of in-hospital stay (days)

In preoperative anaemic patients (days)

In preoperative non-anaemic patients (days)

Mortality

In preoperative anaemic patients

In preoperative non-anaemic patients
Aneurysmal subarachnoid haemorrhage

( $n=5,008)$

22.3 ( \pm 0.3$), 18.0(9.0 ; 28.0)$

$25.3( \pm 0.8), 18.0(9.0 ; 31.0)$

$21.0( \pm 0.4), 17.0(9.0 ; 26.0)$

$16.4 \%(15.4 \%-17.4 \%) ; n=820 / 5,008$

$22.2 \%(19.9 \%-24.6 \%) ; n=270 / 1,218$

$13.3 \%(12.1 \%-14.5 \%) ; n=410 / 3,086$
Intracerebral haemorrhage

$(n=4,073)$

$23.7( \pm 0.4), 16.0(8.0 ; 29.0)$

$25.0( \pm 0.8), 15.0(8.0 ; 30.0)$

$23.0( \pm 0.6), 16.0(9.0 ; 27.0)$

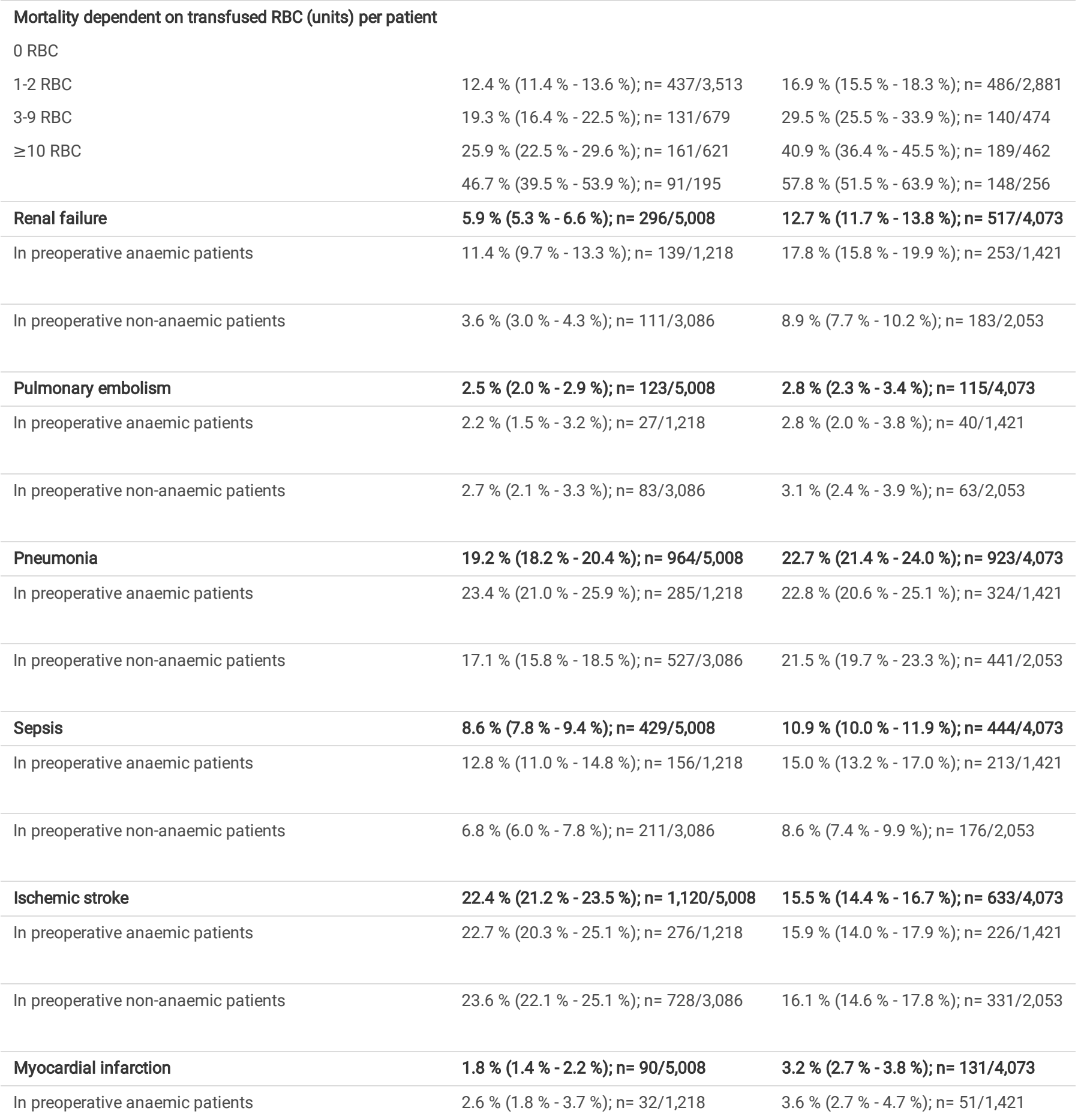

Page $11 / 18$ 
Table 2 shows the postoperative outcomes depending on anaemia status. All values are represented as mean ( \pm SE), median (IQR) or as rate (95\% Cl) and total number.

Table 3) RBC-Transfusion

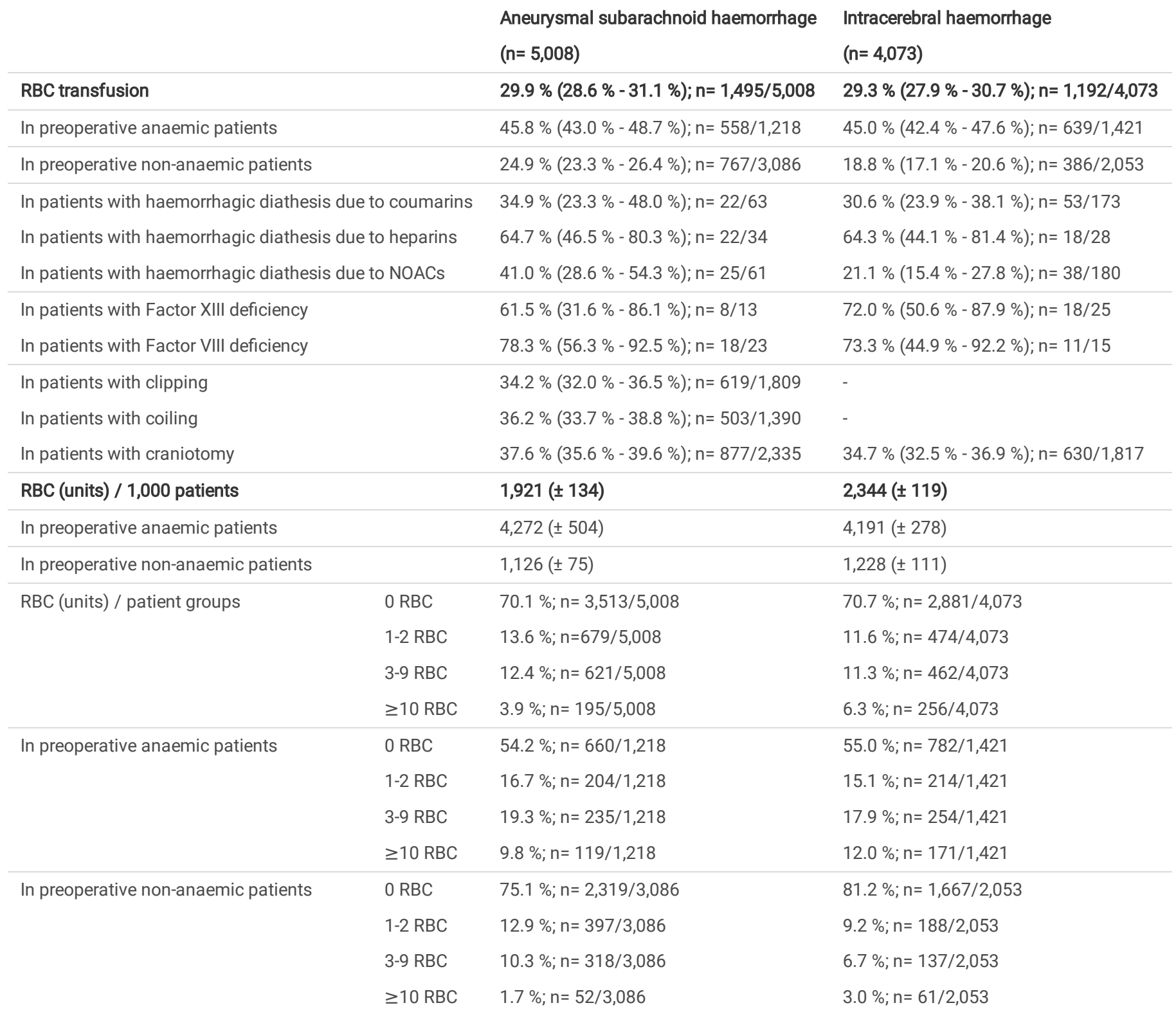

Table 3 shows the transfusion rates and number of RBC unitis per 1000 patients. Subanalyses were performed according to anaemia status, bleeding due to anticoagulation, factor deficiency or pro-bleeding interventions.

NOACs: Novel oral anticoagulants. All values are represented as mean $( \pm \mathrm{SE})$ or as rate $(95 \% \mathrm{Cl})$ and total number.

Table 4) Platelet, Plasma, Fibrinogen, Prothrombin complex concentrate administration 


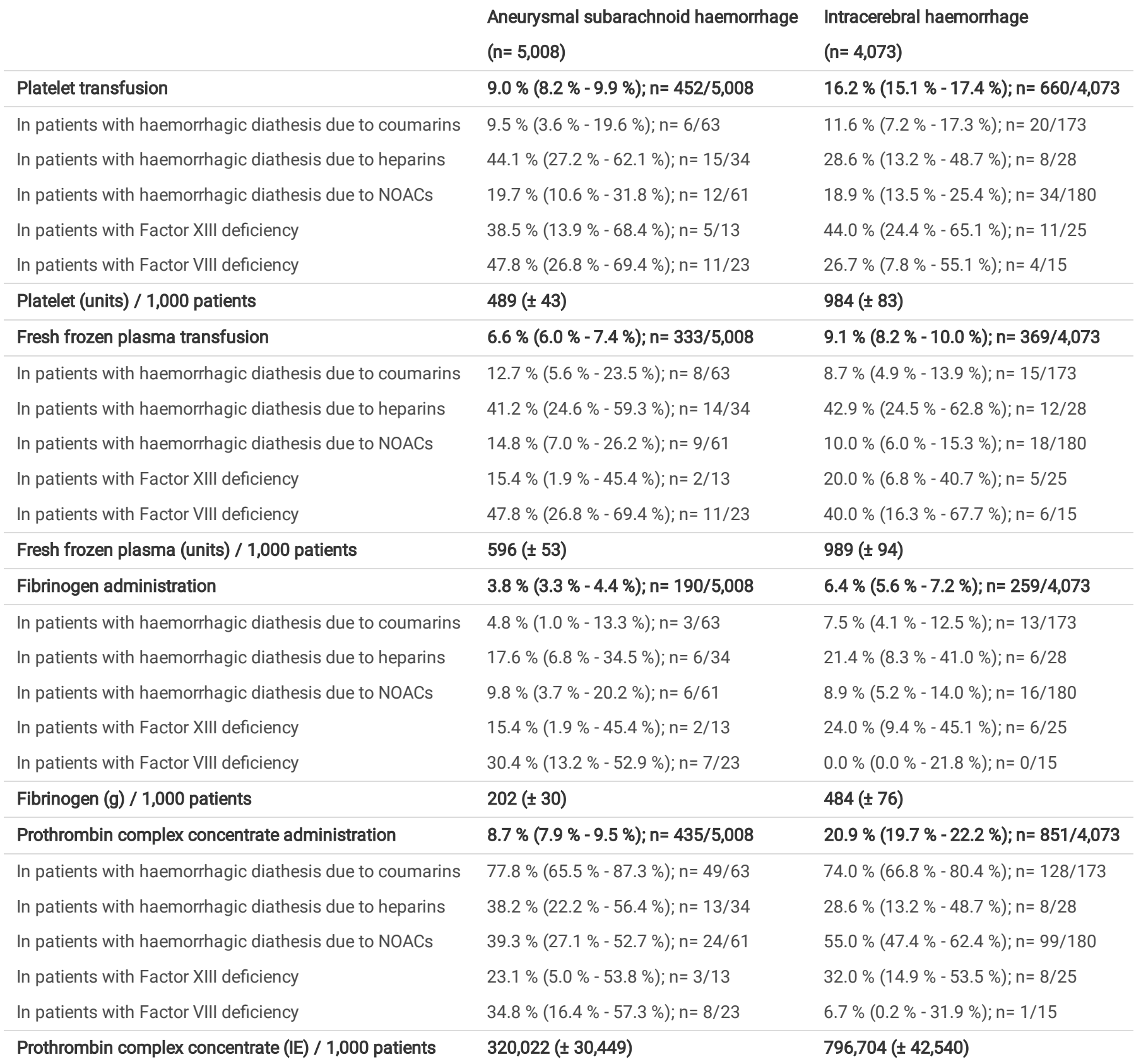

Table 4 shows the administration rates for platelet, plasma, fibrinogen and prothrombin complex concentrate administration in aSAH and ICH patients. Subanalyses were performed for factor deficiency syndromes and anticoagulants. All values are represented as mean ( $\pm \mathrm{SE})$ or as rate (95\% $\mathrm{Cl})$ and total number.

Table 5) Multivariate regression analysis: Risk factors on postoperative outcomes for aSAH patients 


\begin{tabular}{|c|c|c|c|c|c|c|c|c|c|c|c|}
\hline $\begin{array}{l}\text { Outcomes: } \\
\rightarrow\end{array}$ & Vasospasm & $\begin{array}{l}\mathrm{RBC} \\
\text { transfusion }\end{array}$ & Mortality & LOS & $\begin{array}{l}\text { RBC } \\
\text { units/1000 } \\
\text { patients }\end{array}$ & $\begin{array}{l}\text { Postoperative } \\
\text { anaemia }\end{array}$ & $\begin{array}{l}\text { Hospital } \\
\text { acquired } \\
\text { anaemia }\end{array}$ & $\begin{array}{l}\text { Myocardial } \\
\text { infarction }\end{array}$ & $\begin{array}{l}\text { Ischaemic } \\
\text { stroke }\end{array}$ & $\begin{array}{l}\text { Renal } \\
\text { failure }\end{array}$ & $!$ \\
\hline $\begin{array}{l}\text { Risk factors: } \\
\downarrow\end{array}$ & - & - & & & - & & & & & & \\
\hline $\begin{array}{l}\text { Age (per } \\
\text { increase of } \\
10 \text { years) }\end{array}$ & $\begin{array}{l}P<0.001 ; \\
O R=0.82 \\
(0.75-0.89)\end{array}$ & $\begin{array}{l}P<0.001 ; \\
O R=1.11 \\
(1.06-1.17)\end{array}$ & $\begin{array}{l}P<0.001 ; \\
O R= \\
1.27 \\
(1.19- \\
1.36)\end{array}$ & n.s. & n.s. & $\begin{array}{l}\mathrm{P}<0.001 ; \mathrm{OR}= \\
1.14(1.07- \\
1.21)\end{array}$ & $\begin{array}{l}\mathrm{P}=0.001 ; \\
\mathrm{OR}=1.12 \\
(1.04- \\
1.20)\end{array}$ & $\begin{array}{l}P<0.001 ; \\
O R=1.32 \\
(1.13-1.54)\end{array}$ & $\begin{array}{l}\text { n.s. } \\
P=0.06 \\
O R=1.06 \\
(1.00- \\
1.12)\end{array}$ & $\begin{array}{l}\mathrm{P}=0.007 ; \\
\mathrm{OR}= \\
1.15 \\
(1.04- \\
1.27)\end{array}$ & $r$ \\
\hline $\begin{array}{l}\text { Gender } \\
\text { (female vs } \\
\text { male) }\end{array}$ & $\begin{array}{l}\mathrm{P}=0.02 ; \\
\mathrm{OR}=1.32 \\
(1.04-1.68)\end{array}$ & $\begin{array}{l}P<0.001 ; \\
O R=1.51 \\
(1.30-1.75)\end{array}$ & $\begin{array}{l}P=0.002 ; \\
O R= \\
0.76 \\
(0.63- \\
0.90)\end{array}$ & $\begin{array}{l}P<0.001 \\
-3.0 \pm \\
0.6 \text { day }\end{array}$ & $\begin{array}{l}P=0.053 \\
-604 \pm 312\end{array}$ & n.s. & n.s. & $\begin{array}{l}P=0.01 \\
O R=0.58 \\
(0.38-0.89)\end{array}$ & $\begin{array}{l}P=0.01 ; \\
O R=0.82 \\
(0.70- \\
0.96)\end{array}$ & $\begin{array}{l}P<0.001 ; \\
O R=0.50 \\
(0.38- \\
0.67)\end{array}$ & $\begin{array}{l}\text { F } \\
\text { ( } \\
\text { ( }\end{array}$ \\
\hline $\begin{array}{l}\text { Preoperative } \\
\text { anaemia }\end{array}$ & $\begin{array}{l}P=0.01 ; \\
O R=0.70 \\
(0.53-0.92)\end{array}$ & $\begin{array}{l}\mathrm{P}<0.001 ; \\
\mathrm{OR}=3.25 \\
(2.79-3.79)\end{array}$ & $\begin{array}{l}P<0.001 ; \\
\text { OR= } \\
1.48 \\
(1.23- \\
1.79)\end{array}$ & $\begin{array}{l}\mathrm{P}=0.03 \\
1.6 \pm 0.7 \\
\text { day }\end{array}$ & $\begin{array}{l}P<0.001 \\
3033 \pm \\
339\end{array}$ & $\begin{array}{l}P<0.001 ; O R= \\
6.18(4.61- \\
8.28)\end{array}$ & - & n.s. & $\begin{array}{l}P=0.005 ; \\
O R=0.78 \\
(0.65- \\
0.93)\end{array}$ & $\begin{array}{l}\mathrm{P}=0.002 ; \\
\mathrm{OR}= \\
1.61 \\
(1.20- \\
2.16)\end{array}$ & $r$ \\
\hline Clipping & $\begin{array}{l}P<0.001 ; \\
O R=2.10 \\
(1.60-2.76)\end{array}$ & n.s. & $\begin{array}{l}P<0.001 ; \\
\text { OR= } \\
0.40 \\
(0.31- \\
0.52)\end{array}$ & n.s. & $\begin{array}{l}P=0.035 \\
-679 \pm 322\end{array}$ & n.s. & $\begin{array}{l}\mathrm{P}=0.02 ; \\
\mathrm{OR}=1.41 \\
(1.06- \\
1.87)\end{array}$ & $\begin{array}{l}P<0.001 ; \\
O R=4.18 \\
(2.71-6.45)\end{array}$ & n.s. & $\begin{array}{l}P<0.001 ; \\
O R= \\
0.26 \\
(0.15- \\
0.42)\end{array}$ & $r$ \\
\hline Coiling & $\begin{array}{l}P<0.001 ; \\
O R=16.23 \\
(12.41- \\
21.23)\end{array}$ & $\begin{array}{l}P<0.001 ; \\
O R=1.63 \\
(1.37-1.94)\end{array}$ & $\begin{array}{l}\mathrm{P}=0.04 \\
\mathrm{OR}= \\
0.80 \\
(0.65- \\
0.99)\end{array}$ & $\begin{array}{l}P=0.006 \\
2.2 \pm 0.8 \\
\text { days }\end{array}$ & n.s. & $\begin{array}{l}\mathrm{P}<0.001 ; \mathrm{OR}= \\
1.86(1.46- \\
2.36)\end{array}$ & $\begin{array}{l}P<0.001 ; \\
O R=2.04 \\
(1.58- \\
2.62)\end{array}$ & n.s. & $\begin{array}{l}P<0.001 \\
O R=1.84 \\
(1.54- \\
2.21)\end{array}$ & $\begin{array}{l}P<0.001 ; \\
O R= \\
0.27 \\
(0.18- \\
0.40)\end{array}$ & $r$ \\
\hline Craniotomy & n.s. & $\begin{array}{l}\mathrm{P}<0.001 \\
\mathrm{OR}=2.30 \\
(1.97-2.69)\end{array}$ & $\begin{array}{l}P<0.001 ; \\
\text { OR= } \\
1.56 \\
(1.24- \\
1.98)\end{array}$ & $\begin{array}{l}P=0.01 \\
-1.7 \pm \\
0.7 \text { days }\end{array}$ & n.s. & $\begin{array}{l}\mathrm{P}<0.001 ; \mathrm{OR}= \\
2.25(1.87- \\
2.72)\end{array}$ & $\begin{array}{l}\mathrm{P}<0.001 \\
\mathrm{OR}=1.89 \\
(1.45- \\
2.47)\end{array}$ & n.s. & $\begin{array}{l}\mathrm{P}<0.001 ; \\
\mathrm{OR}=1.43 \\
(1.21- \\
1.69)\end{array}$ & $\begin{array}{l}P=0.002 ; \\
O R= \\
0.53 \\
(0.36- \\
0.79)\end{array}$ & $\begin{array}{l}\text { f } \\
\text { c } \\
\text { c } \\
\text { ( }\end{array}$ \\
\hline Vasospasm & - & $\begin{array}{l}\mathrm{P}<0.001 ; \\
\mathrm{OR}=2.13 \\
(1.69-2.69)\end{array}$ & n.s. & $\begin{array}{l}P<0.001 \\
6.1 \pm 1.1\end{array}$ & n.s. & $\begin{array}{l}\mathrm{P}=0.004 ; \mathrm{OR}= \\
1.67(1.18- \\
2.36)\end{array}$ & $\begin{array}{l}P=0.006 ; \\
O R=1.66 \\
(1.15- \\
2.39)\end{array}$ & n.s. & $\begin{array}{l}P<0.001 \\
O R=1.76 \\
(1.38- \\
2.25)\end{array}$ & n.s. & $r$ \\
\hline $\mathrm{ICH}$ & n.s. & $\begin{array}{l}P<0.001 ; \\
O R=2.16 \\
(1.84-2.55)\end{array}$ & $\begin{array}{l}P<0.001 ; \\
O R= \\
2.23 \\
(1.83- \\
2.71)\end{array}$ & n.s. & n.s. & $\begin{array}{l}\mathrm{P}<0.001 ; \mathrm{OR}= \\
1.56(1.23- \\
1.97)\end{array}$ & $\begin{array}{l}\mathrm{P}<0.001 \\
\mathrm{OR}=1.69 \\
(1.31- \\
2.18)\end{array}$ & n.s. & $\begin{array}{l}\mathrm{P}=0.05 ; \\
\mathrm{OR}=1.19 \\
(1.00- \\
1.42)\end{array}$ & n.s. & $r$ \\
\hline $\begin{array}{l}\text { RBC } \\
\text { transfusion }\end{array}$ & $\begin{array}{l}P<0.001 ; \\
O R=2.47 \\
(1.94-3.15)\end{array}$ & - & $\begin{array}{l}P<0.001 ; \\
O R= \\
2.30 \\
(1.91- \\
2.78)\end{array}$ & $\begin{array}{l}P<0.001 \\
13.7 \pm \\
0.7\end{array}$ & - & $\begin{array}{l}\mathrm{P}<0.001 ; \mathrm{OR}= \\
4.70(3.51- \\
6.30)\end{array}$ & $\begin{array}{l}P<0.001 \\
O R=7.15 \\
(4.95- \\
10.32)\end{array}$ & $\begin{array}{l}P<0.001 ; \\
O R=0.25 \\
(0.13-0.48)\end{array}$ & $\begin{array}{l}\mathrm{P}<0.001 \\
\mathrm{OR}=3.19 \\
(2.70- \\
3.76)\end{array}$ & $\begin{array}{l}P<0.001 ; \\
O R= \\
12.08 \\
(8.65- \\
16.87)\end{array}$ & $\begin{array}{l}\mathrm{F} \\
\dot{c} \\
\dot{c}\end{array}$ \\
\hline
\end{tabular}

Table 5 shows the results of the multivariate regression analysis to investigate risk factors for postoperative outcomes in aSAH patients. The vertical column lists the risk factors and the horizontal column lists the corresponding outcomes. All values are represented either as Odds ratio (with $95 \% \mathrm{Cl}$ ) for binary endpoints or as difference in mean \pm standard error of mean (SE) for continuous endpoints. Non-significant results and p-values $>0.10$ are marked with n.s..

Table 6) Multivariate regression analysis: Independent risk factors on postoperative outcomes for ICH patients 


\begin{tabular}{|c|c|c|c|c|c|c|c|c|c|c|c|}
\hline $\begin{array}{l}\text { Outcomes: } \\
\rightarrow \\
\text { Risk factors: } \\
\downarrow\end{array}$ & $\begin{array}{l}\mathrm{RBC} \\
\text { transfusion }\end{array}$ & Mortality & LOS & $\begin{array}{l}\text { RBC } \\
\text { units/1000 } \\
\text { patients }\end{array}$ & $\begin{array}{l}\text { Postoperative } \\
\text { anaemia }\end{array}$ & $\begin{array}{l}\text { Hospital } \\
\text { acquired } \\
\text { anaemia }\end{array}$ & $\begin{array}{l}\text { Myocardial } \\
\text { infarction }\end{array}$ & $\begin{array}{l}\text { Ischaemic } \\
\text { stroke }\end{array}$ & $\begin{array}{l}\text { Renal } \\
\text { failure }\end{array}$ & Sepsis & Pnel \\
\hline $\begin{array}{l}\text { Age (per } \\
\text { increase of } \\
10 \text { years) }\end{array}$ & $\begin{array}{l}P<0.001 \\
O R=0.89 \\
(0.84-0.94)\end{array}$ & $\begin{array}{l}P<0.001 ; \\
\text { OR= } \\
1.18 \\
(1.11- \\
1.25)\end{array}$ & $\begin{array}{l}P<0.001 \\
-1.0 \pm \\
0.3 \text { days }\end{array}$ & $\begin{array}{l}P<0.001 \\
-661 \pm 90\end{array}$ & $\begin{array}{l}\mathrm{P}=0.006 ; \mathrm{OR}= \\
1.10(0.60- \\
1.65)\end{array}$ & $\begin{array}{l}P=0.004 ; \\
O R= \\
1.11 \\
(1.04- \\
1.20)\end{array}$ & $\begin{array}{l}P=0.01 ; \\
O R=1.18 \\
(1.04-1.36)\end{array}$ & n.s. & n.s. & $\begin{array}{l}P<0.001 ; \\
O R= \\
0.85 \\
(0.79- \\
0.91)\end{array}$ & n.s. \\
\hline $\begin{array}{l}\text { Gender } \\
\text { (female vs } \\
\text { male) }\end{array}$ & $\begin{array}{l}P=0.003 ; \\
O R=1.28 \\
(1.09-1.50)\end{array}$ & n.s. & $\begin{array}{l}P<0.001 \\
-3.4 \pm \\
0.9 \text { days }\end{array}$ & n.s. & $\begin{array}{l}P<0.001 ; O R= \\
0.63(0.52- \\
0.77)\end{array}$ & $\begin{array}{l}P<0.001 ; \\
O R= \\
0.68 \\
(0.55- \\
0.84)\end{array}$ & $\begin{array}{l}P<0.001 ; \\
O R=0.44 \\
(0.30-0.66)\end{array}$ & n.s. & $\begin{array}{l}P<0.001 \\
O R= \\
0.57 \\
(0.46- \\
0.70)\end{array}$ & $\begin{array}{l}P<0.001 ; \\
\text { OR= } \\
0.67 \\
(0.54- \\
0.84)\end{array}$ & $\begin{array}{l}P<0.1 \\
O R= \\
(0.4 \subseteq\end{array}$ \\
\hline $\begin{array}{l}\text { Preoperative } \\
\text { Anaemia }\end{array}$ & $\begin{array}{l}P<0.001 ; \\
O R=4.16 \\
(3.54-4.89)\end{array}$ & $\begin{array}{l}P<0.001 \\
O R=1.53 \\
(1.29- \\
1.82)\end{array}$ & $\begin{array}{l}P=0.006 \\
-2.5 \pm \\
0.9 \text { days }\end{array}$ & $\begin{array}{l}P<0.001 \\
2881 \pm \\
264\end{array}$ & $\begin{array}{l}\mathrm{P}<0.001 ; \mathrm{OR}= \\
7.11(5.30- \\
9.54)\end{array}$ & - & n.s. & $\begin{array}{l}P=0.05 \\
O R=0.82 \\
(0.67- \\
1.00)\end{array}$ & n.s. & n.s. & $\begin{array}{l}P=0 . \\
O R= \\
(0.65\end{array}$ \\
\hline Craniotomy & $\begin{array}{l}P<0.001 ; \\
O R=1.78 \\
(1.49-2.08)\end{array}$ & $\begin{array}{l}P=0.01 \\
O R=0.80 \\
(0.67- \\
0.95)\end{array}$ & $\begin{array}{l}P<0.001 \\
-5.3 \pm \\
0.9 \text { days }\end{array}$ & $\begin{array}{l}P<0.001 \\
-1263 \pm \\
268\end{array}$ & $\begin{array}{l}\mathrm{P}<0.001 ; \mathrm{OR}= \\
1.76(1.43- \\
2.16)\end{array}$ & $\begin{array}{l}P<0.001 ; \\
O R= \\
1.79 \\
(1.45- \\
2.22)\end{array}$ & $\begin{array}{l}P=0.008 \\
O R=0.60 \\
(0.41-0.88)\end{array}$ & $\begin{array}{l}P=0.005 \\
O R=1.31 \\
(1.08- \\
1.60)\end{array}$ & $\begin{array}{l}\mathrm{P}<0.001 \\
\mathrm{OR}=0.37 \\
(0.30- \\
0.46)\end{array}$ & $\begin{array}{l}P<0.001 ; \\
O R=0.34 \\
(0.27- \\
0.43)\end{array}$ & $\begin{array}{l}\mathrm{P}<0 . \\
\mathrm{OR}= \\
(0.62\end{array}$ \\
\hline $\begin{array}{l}\text { RBC } \\
\text { transfusion }\end{array}$ & - & $\begin{array}{l}P<0.001 \\
O R=3.59 \\
(3.00- \\
4.30)\end{array}$ & $\begin{array}{l}P<0.001 \\
+17.7 \pm \\
1.0 \text { days }\end{array}$ & - & $\begin{array}{l}\mathrm{P}<0.001 ; \mathrm{OR}= \\
7.34(4.96- \\
10.87)\end{array}$ & $\begin{array}{l}P<0.001 ; \\
O R= \\
8.14 \\
(5.16- \\
12.86)\end{array}$ & $\begin{array}{l}P<0.001 ; \\
O R=3.57 \\
(2.48-5.15)\end{array}$ & $\begin{array}{l}P<0.001 ; \\
O R=2.13 \\
(1.73- \\
2.62)\end{array}$ & $\begin{array}{l}P<0.001 \\
O R=9.45 \\
(7.60- \\
11.75)\end{array}$ & $\begin{array}{l}P<0.001 ; \\
\text { OR=7.92 } \\
(6.27- \\
9.99)\end{array}$ & $\begin{array}{l}P<0.1 \\
\mathrm{OR}= \\
(2.7 \Sigma\end{array}$ \\
\hline
\end{tabular}

Table 6 shows the results of the multivariate regression analysis to investigate risk factors for postoperative outcomes in ICH patients. The vertical column lists the risk factors and the horizontal column lists the corresponding outcomes. All values are represented either as Odds ratio (with $95 \% \mathrm{Cl}$ ) for binary endpoints or as difference in mean \pm standard error of mean (SE) for continuous endpoints. Non-significant results and $\mathrm{p}$-values $>0.10$ are marked with $\mathrm{n} . \mathrm{s}$..

\section{Figures}




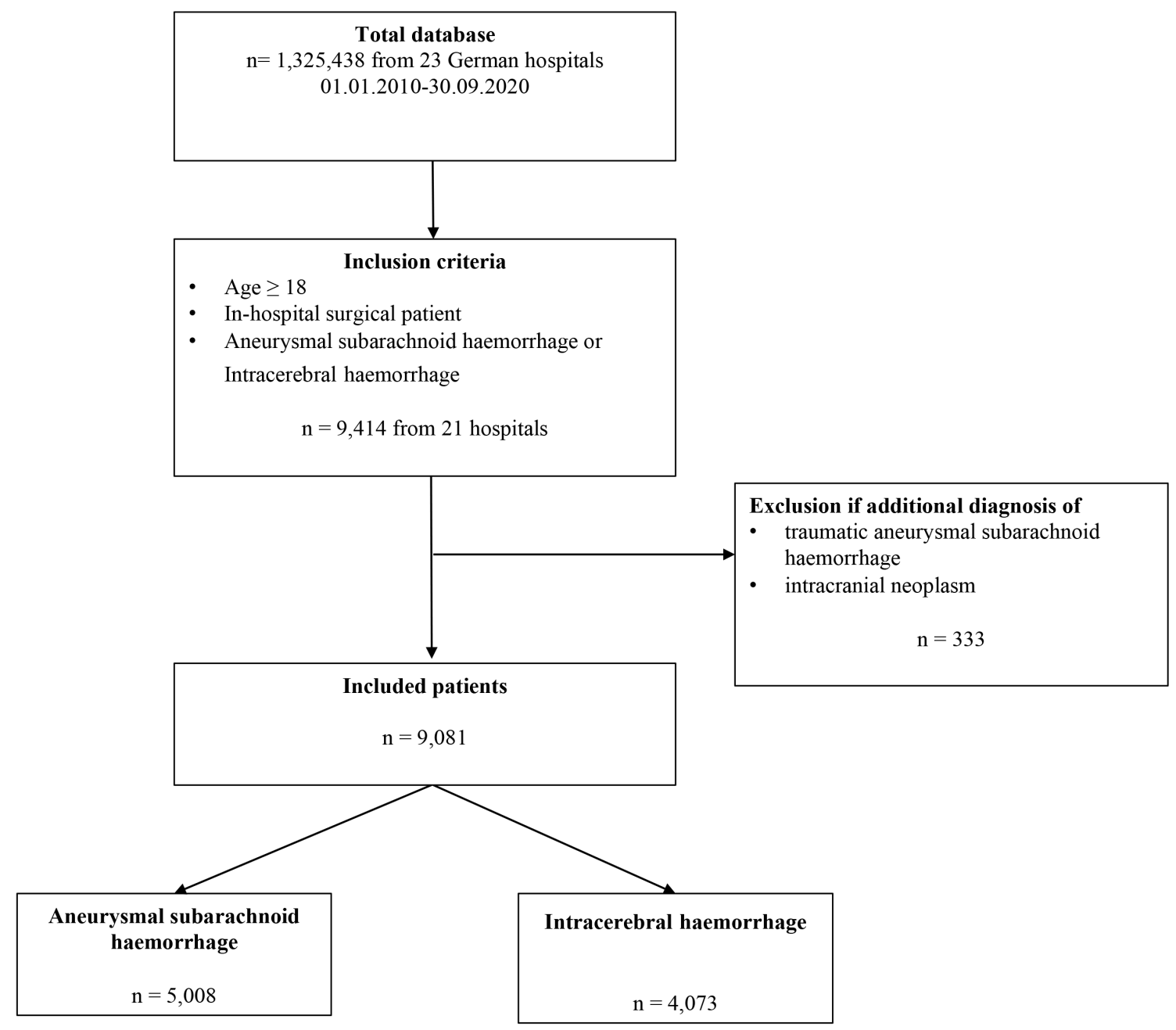

Figure 1

illustrates the inclusion and exclusion criteria among patients analysed 
$\mathrm{ICH}$ patients

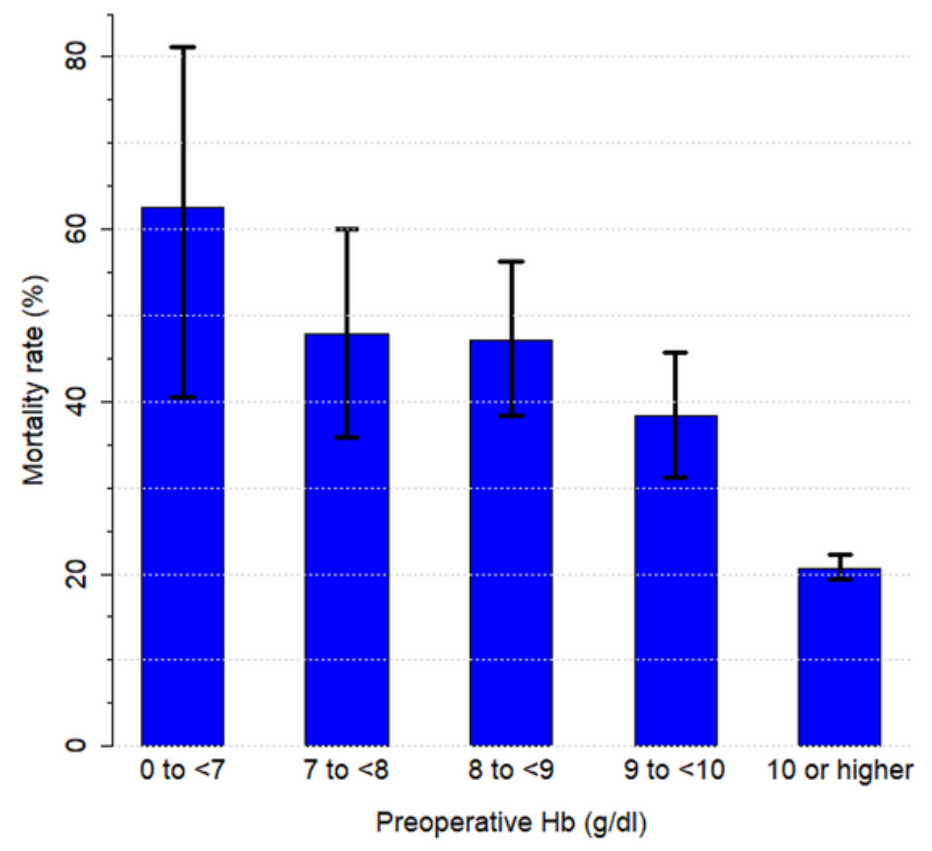

A
ICH patients

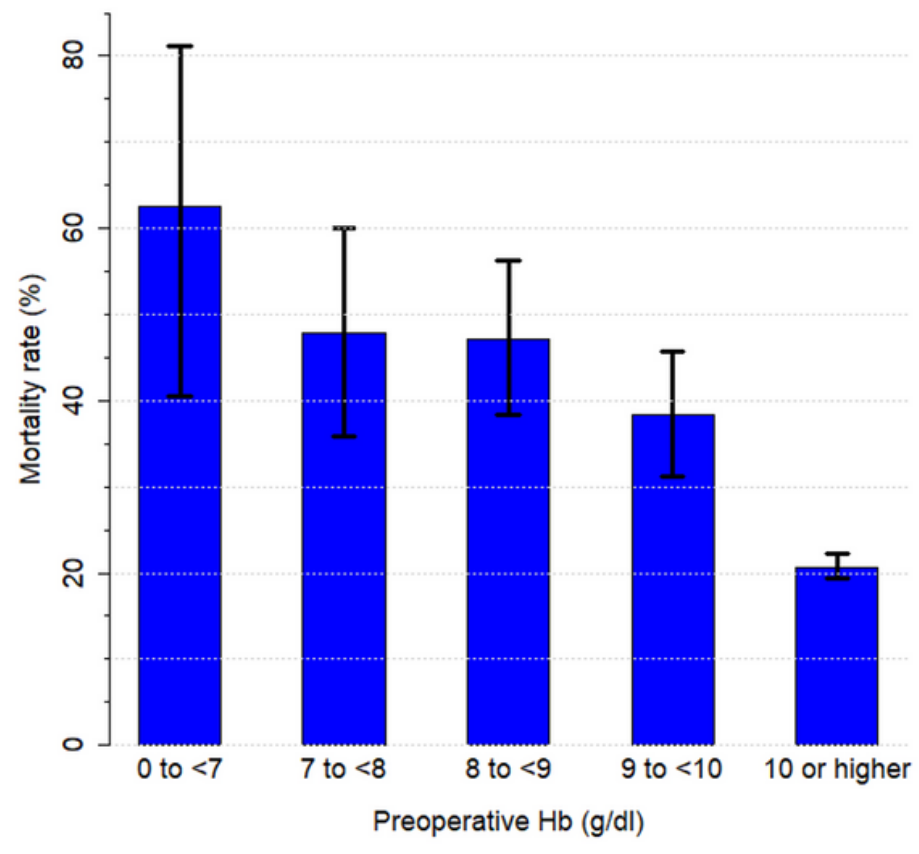

B

Figure 2

illustrates the mortality rate dependent on the preoperative $\mathrm{Hb}$ values for a) Aneurysmal subarachnoid haemorrhage (aSAH) and b) Intracerebral haemorrhage (ICH). 95\% confidence intervals (error bars) are shown.
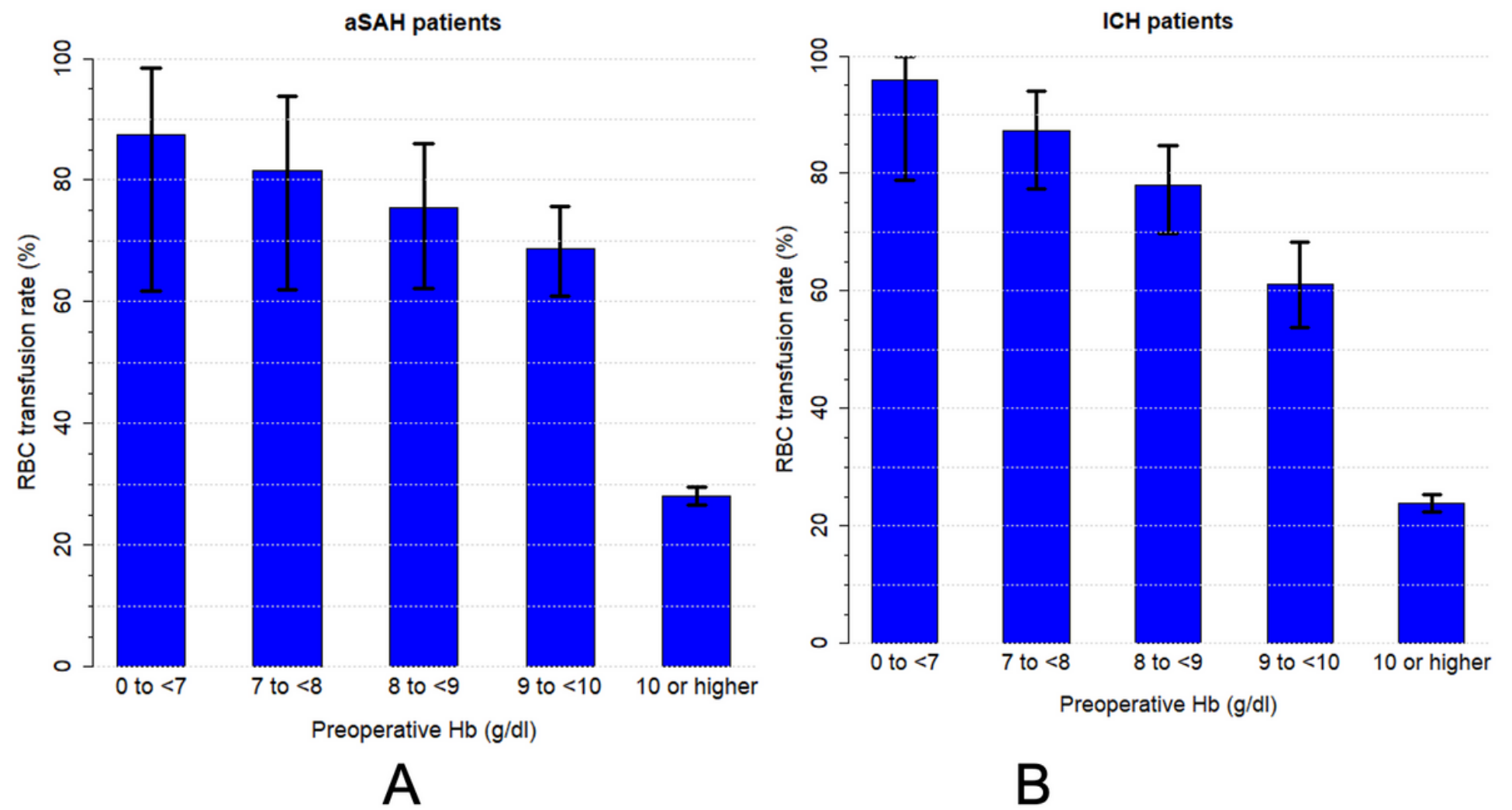

Figure 3 
illustrates the RBC transfusion rate dependent on the preoperative $\mathrm{Hb}$ values for a) Aneurysmal subarachnoid haemorrhage (aSAH) and b) Intracerebral haemorrhage (ICH). 95\% confidence intervals (error bars) are shown. 